Article

\title{
Laboratory Studies on Granular Filters and Their Relationship to Geotextiles for Stormwater Pollutant Reduction
}

\section{Parneet Paul $^{1,2, *}$ and Kiran Tota-Maharaj ${ }^{3}$}

1 School of Civil Engineering and Construction, Faculty of Science, Engineering and Computing, Kingston University, Kingston upon Thames, Surrey KT1 1LQ, UK

2 Water Sustainability Research Centre, Department of Mechanical, Aerospace and Civil Engineering, Brunel University, London, Uxbridge, Middlesex UB8 3PH, UK

3 Department of Civil Engineering, Faculty of Engineering and Science, University of Greenwich, Medway Campus, Chatham Maritime, Kent ME4 4TB, UK;

E-Mail: K.Tota-Maharaj@greenwich.ac.uk

* Author to whom correspondence should be addressed; E-Mail: p.paul@kingston.ac.uk or parneet.paul@brunel.ac.uk; Tel.: +44-1895-265-435; Fax: +44-1895-274-000.

Academic Editor: Say-Leong Ong

Received: 28 November 2014 / Accepted: 2 April 2015 / Published: 15 April 2015

\begin{abstract}
Applications of geotextiles within tertiary stormwater treatment systems and for stormwater infiltration can provide a substrate for biofilm formation, enabling biological treatment of contaminants. Geotextiles can serve as an efficient part of stormwater filtration within the urban water environment. The project assessed the applications of three experimental granular filters as a sustainable urban drainage system (SUDS) for the decomposition of organic pollutant loading present in stormwater. The three filter rigs were packed with alternating layers of filter media consisting of gravel, pea gravel, sand and either a single, double or no layer of geotextile membrane. A nonwoven geotextile was layered within the filter media. The hydraulic loading capacity for the three filters matched that commonly used with conventional sand filters systems. Water quality parameters were quantified by measuring suspended solids, chemical oxygen demand, dissolved oxygen, $\mathrm{pH}$, nitrate-nitrogen, and phosphate concentrations. It was found that Filter Rig No. 3 (upper and lower geotextile membrane) and Filter Rig No. 2 (single geotextile membrane) had a significant statistical difference in treatment performance from Filter Rig No. 1 (no geotextile membrane).
\end{abstract}


Keywords: adsorption; biofilm; geomembrane; sustainable urban drainage system (SUDS); stormwater harvesting

\section{Introduction}

The controlled treatment of stormwater is critical in the reduction and removal of water pollutants and in ameliorating the risk of groundwater and downstream surface water pollution. Granular filters consisting of sand and gravel have now been used extensively for treatment of domestic wastewater for over a century. These filters are operated either in a single pass or recirculation mode. Geotextiles are used for separation, reinforcement, filtration, drainage and for acting as a barrier within urban drainage designs. Geotextiles orientated specifically for stormwater treatment are still being developed with some being used in drainage systems today. The use of geotextiles for filtration purposes dates back further than any of their other attributes [1]. Geotextiles have been implemented as part of sand filter systems [2]; as a baffle system for a combined sewer overflow [3]; packed in a conduit for septic tank outflows; and, as part of a permeable paving system [4]. There still is insufficient research solely on the effects of geotextiles within stormwater treatment and the effects of various contaminants found within stormwater. This research work is on-going and this study forms part of that work.

Geotextiles are permeable materials that can be woven, unwoven or knitted [5]. Natural geotextiles are commonly used in developing countries since the raw material is often in abundance and cheaper than the synthetic equivalents. However, natural geotextiles often experience a lower resistance to degradation than their synthetic equivalents. Synthetic geotextiles are typically either formed from polypropylene or polyethylene terephthalate [5]. Typically in construction, geotextiles are placed down gradient of the soil to be filtered. Water passes through the geotextile at a normal to the plane of flow, blocking any soil particles larger than the pore size from passing through. This allows for the use of geotextiles in roadside drainage as they provide some filtration to surface run-off. Another use is in permeable pavement systems where the filtered water is intended to be discharged into the ground and where the water proofed membrane is used in systems where a higher concentration of pollution (e.g., petrol and oils) in the water demands further treatment before discharge. The use of geotextiles in filtration systems all assume they are capable of sustaining a certain amount of structural load due to other layers present above the geotextile. It is assumed that this causes the geotextiles to compress thus decreasing the space between fibres, or pore space. The impact of this compression means that a geotextile will become prone to clogging as demonstrated in a recent study where the drainage and filtration properties of nonwoven geotextiles under confinement were explored and the pore size measured as the applied normal stress was increased [6]. This means a greater retention time within the geotextiles occurs in practice particularly as the pores become clogged by soil particles that have been filtered [7]. This supports the results which indicate that as the applied normal stress is increased, the geotextile's permeability reduces.

The use of geotextiles in conjunction with soil filters have been used in drainage systems for leachate management from landfill sites [8]. The geotextiles were initially installed to act as a barrier to avoid soil particles from reaching and clogging a geosynthetic drain. However, it was noticed that the 
geotextile itself was performing much of the filtration. Koerner and Koerner [8] designed a number of experiments to test the change of permeability in the soil/geotextile filter system over time, and assessed potential remediation techniques to recover it. The permeability of the system, measured using a permeameter, was shown to reduce over the 20 month experimental period; however this could be recovered by back flushing the system to remove clogging by both soil particles and bacterial growth as biofilm. The research also showed that the geotextile filters appear to be less vulnerable to clogging when compared to soil filters alone (as applied in leaching field context), and concluded with several recommendations for usage of woven and nonwoven geotextiles alike [8].

It may be noted that whilst geomembranes also form part of the category of geosynthetics, they are impermeable to water and therefore are used in projects where it essential for a hydraulic barrier. Investigations have been conducted to review the use of geotextiles to host biomass facilitating biological treatment, in order to reduce levels of total suspended solids (TSS), biochemical oxygen demand (BOD5) and ammonia-nitrogen $\left(\mathrm{NH}_{3}\right)$. Yaman et al. [2] found that falling levels of permeability associated with clogging can be reduced by applying a dose and drain cycle feeding onto the system rather than a continuous feed operation, and recommended the use of two layers of geotextiles for improved filtration and permeability. Figure 1 illustrates how the permeability of a geotextile stabilises by limitations on the growth of biofilm in and around the pore spaces. This is due to the outer layers limiting the oxygen required by the bacteria closer to the fibres, and thereby potentially achieving anaerobic conditions deeper within the biofilm zone [2]. The biofilm forms within pores of the geotextile, rather than in the gravels and sands adjacent. This helps reduce the clogging in the overall system and maintains stable hydraulic loading rates when compared to standard sand filter systems. The drawback to having only aerobic treatment as part of the design is a reduction in treatment efficacies of nitrates requiring longer retention times from filtration. The stormwater itself has high dissolved oxygen levels ( $>5 \mathrm{mg} / \mathrm{L}$ ) due to entrained oxygen gained as it flows through the surface drains and as it percolates through the pores of the filter media. This means that the bulk of stormwater treatment occurring is treated aerobically (removing dissolved organic matter and suspended particles) as it flows through the fixed biofilm zone around the geotextile layer. However, it must be noted that simultaneous anaerobic treatment takes place within pockets of the thickened biofilm where concentrations of attached flocs are greatest. As such, the suggestion that the biofilm has anaerobic zones within it indicates that a higher level of reduction can be achieved. Thus it is theorised that the suspended and dissolved organic matter in the stormwater is treated both aerobically and anaerobically by the fixed biofilm and any adjacent suspended flocs. This situation is desirable as it produces fewer by-products [9].
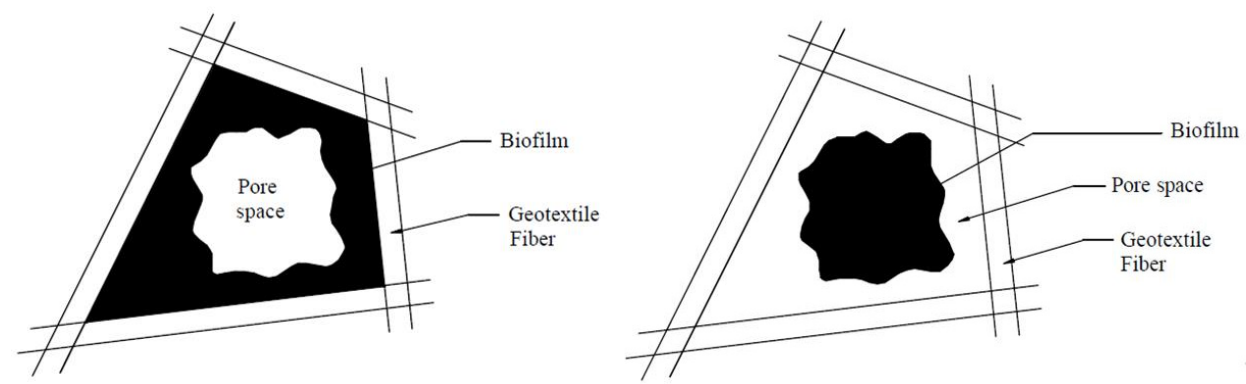

Figure 1. Two models for biomass accumulation in a fibrous geotextile structure (adapted after [2]). 
The aim of this study was to assess the optimal design of geotextile filtration systems as a way to protect receiving waters from pollution discharges within urbanised environments. The main objectives of this research project were to further develop the use of geotextile membranes as a potential sustainable urban drainage system (SUDS) for urban stormwater treatment. This would in turn enhance the available water reuse strategies. Several key issues were addressed in this initial research work as follows:

- Does the introduction of a cost effective geotextile layer within the standard granular filter system enhance biochemical treatment performance? Is the number and location of the geotextile layer/s in relation to the granular filter layers important in determining the extent of treatment achieved?

- Does the addition of a further geotextile layer improve treatment efficiency whilst reducing the overall depth of the granular filter layers? Could this be a way of cost effectively reducing volumes of materials needed in granular stormwater filter systems?

- Was there a significant difference in the formation, growth and thickness of the biofilm that carries out the bulk of the treatment on the different geotextile membrane layers? Does any differences in biofilm formation match theory and expectations?

This study forms part of a much larger research effort some of which is described in Tota-Maharaj and Paul [10]. Thus this work is an initial phase of research work that looks at the applicability of adding geotextile layering into the granular filter media layers, and its overall impact on stormwater treatment, volumetric loading throughput and associated biofilm formation.

\section{Materials and Methods}

Three cylindrical water butts were obtained to house the various layers of aggregate and geotextile that were used in the experiments. Each had a volumetric capacity of 200 L. The water butts were filled with layers of filter media including sand, pea gravel, gravel and as necessary geomembrane layer or layers according to the configurations shown in Figures 2 and 3. Each water butt was equipped with a drainage tap at the base. These taps were checked for leaks prior to the beginning of the investigation and were sealed using a rubber sealant (Figure 3).

A standard, cost effective, commercially available geotextile filter was selected that was made from a non-woven fabric having a $180 \mu \mathrm{m}$ pore size. This specific geotextile was designed for applications in drainage, filtration and separation systems (Terram Geosynthetics, Essex, UK). The geotextile filter used in Filter Rigs No. 2 and No. 3 had a design permeability of $100 \mathrm{~L} / \mathrm{m}^{2} . \mathrm{s}$ and a thickness of $0.9 \mathrm{~mm}$. The geotextiles were manufactured from UV (ultra-violet) stabilised, high tenacity, polypropylene fibres that were both mechanically and thermally bonded to provide high strength and excellent filterability characteristics. Significant factors affecting the flow velocity such as the porosity values for the filter media (i.e., sand, pea gravel and gravel layers) embedded into the granular filters and relevant depths with corresponding saturation volumes are presented in detail in Tota-Maharaj and Paul [10]. The aggregates and filter media used to make up the sand and gravel layers were commercially available (Table 1). Specialist dry sand was used for the middle layers, whilst a coarse gravel and pea gravel were used in the lower and upper layers in each rig (Figures 2 and 3). 


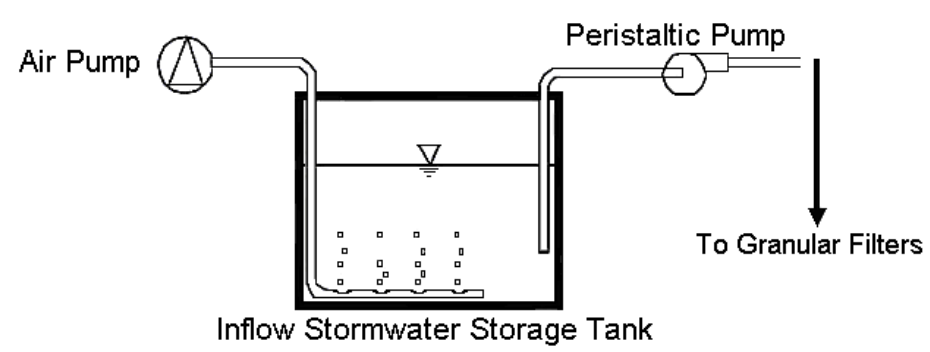

(a)

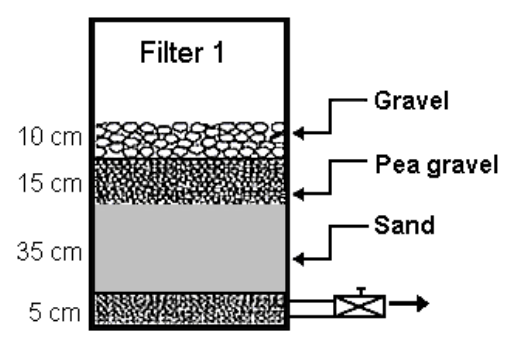

(b)

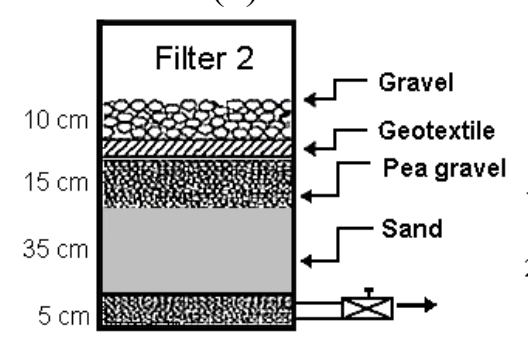

(c)

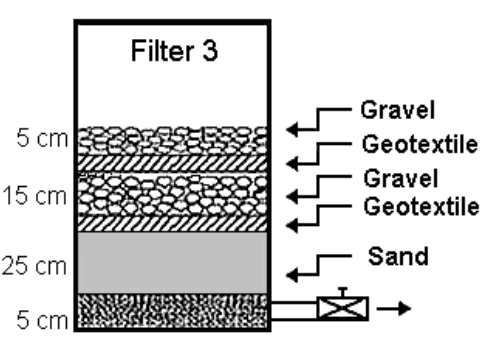

(d)

Figure 2. (a) Storage tank for stormwater undergoing aeration and prior to pumping to filters; (b-d) Granular Filter Rigs Nos. 1, 2 and 3 with varying layers of gravel, pea gravel, sand and geotextile membrane.

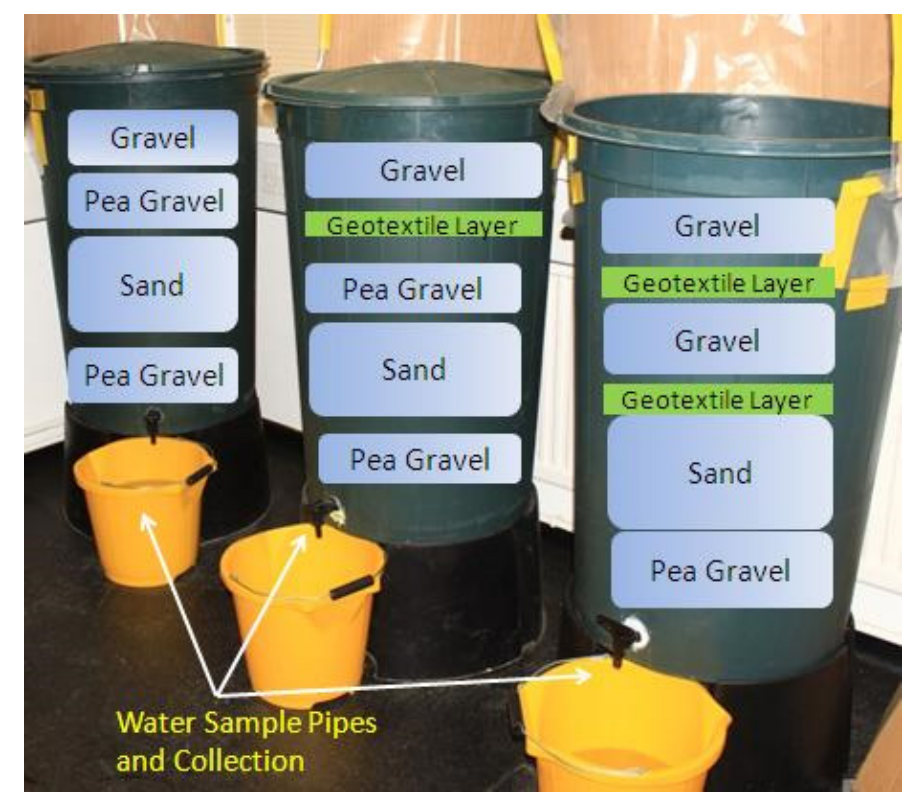

Figure 3. From Left to Right - Granular Filter Rigs Nos. 1, 2 and 3 with varying layers of gravel, pea gravel, sand and geotextile membrane.

Table 1. Aggregates and filter media used in the granular filtration system.

\begin{tabular}{ccc}
\hline Filter Media & Product & Approx. Size (mm) \\
\hline Sand & Leighton Buzzard BS16/30 & $0.5-1.00$ \\
Pea Gravel & Amber Flint & 6 \\
Coarse Gravel & Pink Granite & 20 \\
\hline
\end{tabular}


A water-proof commercially based rubber sealant was used as a temporary barrier between the geotextile and the water butt internal wall to prevent any possibilities of hydraulic short-circuiting. Additionally, biofilm growth was visually measured with periodic membrane autopsies, and carried out at one-third the distance from the rig's wall to represent a typical location on the geotextile surface whereby most representative samples usually occurred. The experimental rigs were kept at a room temperature $\left(20^{\circ} \mathrm{C}\right)$ throughout the analysis. The particle size specifications for granular media used was D10 for sand, and D50 for gravel and pea gravel respectively. The D50 particle diameter for gravel and pea gravel represented $50 \%$ of the gravel particles (by weight).

Unlike conventional sand filters the order particle size distribution of the aggregates are essentially reversed [11]. The depths for the different layers were set whereby the largest aggregate volume (sand) acts as an attenuating segment and slows the flow of the water through the rigs, thus increasing contact time within the geotextile layers. The upper coarse gravel layer role is to both dissipate energy from the water before reaching the geotextile layers and also to evenly distribute the water across the surface area [12]. The large volumes of space between the larger aggregates and grains allows for the movement of air, encouraging the extraction of air during the dose/drain cycle and creating aerobic conditions leading to some natural degradation. The upper pea gravel layers also dissipate energy from the water and provide a housing and support for the geotextile membrane. The lower layers of pea and coarse gravel were employed to limit the travel of sand and into the taps and act as a tertiary stage filtration for the final effluent.

The configuration of Filter Rig No. 1 and Filter Rig No. 2 was almost identical volume wise apart from the addition of the single thin geotextile layer in the second rig. The difference, volume wise, between these two rigs and Filter Rig No. 3 was marked, with less filter media being used overall whilst an additional geotextile layer was added. This comparative experiment tested the effectiveness of volumetric flows used within the sub-base layer based on the cost of materials used for the same application. Thus it was carried out to see whether with an additional geotextile membranes layer with an associated $15 \%$ drop in volume of granular filter media used (and thus associated cost), allowed the system's treatment performance to be improved or equally caused a deterioration since there would be less sub-base filler material such as sand and gravel to treat the same quality and quantity of stormwater. In terms of a full scale system, a considerable saving could be made in not only the volumes of materials needing to be transported and placed in situ, but also the amount of cut and fill actually required since potentially shallower profiles could be used. Shallower depths would also make recharging the system's permeability by periodic back washing of the media and replacing or cleaning the geotextile membrane an easier operation to carry out.

The influent stormwater used was a mixture of river water from the River Pinn, London, and gully pot liquors. Gully pots are small settling chambers or sumps located along roadsides and covered with a protective cast iron grating, used to treat surface runoff entering the drainage system by removing its high organic pollutant load [13]. The granular filter rigs operated in a batch-fed single pass mode under gravity, i.e., the stormwater mixture flows through the filter only once from top to bottom. The stormwater mixture was distributed evenly over the upper surface of the filter using a system of a splash deck and a small perforated pipe network. The water then drained through the system, finally accumulating in the sub-base zone of the filter, and could be collected from the outlet pipe. This collected water could then be sampled for water quality analysis. This method was used due to its simplicity and low energy 
requirements, as opposed to a recirculating filter which would require extra energy to pump filtrate to the top to mix with incoming stormwater influent before cycling through the system again.

The efficacy of the three experimental granular filter rigs was compared by analysing various water quality parameters including suspended solid matter as TSS, chemical oxygen demand (COD), dissolved oxygen (DO), $\mathrm{pH}$, temperature, conductivity, nitrate-nitrogen $\left(\mathrm{NO}_{3}-\mathrm{N}\right)(\mathrm{mg} / \mathrm{L})$, and phosphates $\left(\mathrm{PO}_{4}{ }^{3-}\right)$ $(\mathrm{mg} / \mathrm{L})$. All water quality parameters were determined using the American Water and Wastewater Association's Standard Methods [14]. A Hanna H1991300 meter was used for temperature and pH measurement, with a precision of $\pm 0.5^{\circ} \mathrm{C}$ and for $\mathrm{pH} \pm 0.1$. Two additional Hanna meters $\mathrm{H} 19033$ and H19142 were used to measure conductivity and DO with a precision of $\mu \mathrm{S} / \mathrm{cm} \pm 1 \%$ full scale, and $\pm 0.8 \mathrm{mg} / \mathrm{L}$ respectively. $\mathrm{NO}_{3}-\mathrm{N}(\mathrm{mg} / \mathrm{L})$ was measured using the cadmium reduction method with a Hach spectrophotometer (Hach Lange, Salford, UK) [15,16] and $\mathrm{PO}_{4}{ }^{3-}(\mathrm{mg} / \mathrm{L})$ was measured using the Amino Acid Method with the same spectrophotometer. The COD content was analysed using a Hach DRB 200 spectrophotometer using the dichromate/sulphuric acid digestion method $[15,16]$. In addition to the water quality tests, an optical microscope connected to a computer was used to take images of the various geotextile layers in Filter Rigs No.2 and No.3 using a standard membrane autopsy procedure. These images were then compared in order to identify any differences in the composition of the biofilm, and whether the biofilm had accumulated on the surface of the geotextile fibres or whether it was suspended largely in the pore spaces between the fibres. Further, the microscopic images were used to gauge, observationally, as to whether there was more or less biofilm growth for each autopsy sample, and whether this correlated with theory and expectation in terms of hydraulic throughput and treatment mechanisms occurring. Multivariate analysis of variance (MANOVA) which is an extension of the standard analysis of variance (ANOVA) procedure was used to statistical compare and correlate results since several dependent and independent variables were used in the experimental setup. The MANOVA statistical tests evaluated for differences in two or more vectors of means.

\section{Results and Discussion}

The water quality parameters for the inflow stormwater mixture (combined water from the River Pinn, London and gully pot liquors) are presented in Table 2 . It can be seen that the stormwater quality is in the typical range expected, and of generally low to moderate strength in terms of the COD, TSS and $\mathrm{NO}_{3}-\mathrm{N}$ values.

Table 2. Inflow stormwater composition and mixture (i) range (minimum-maximum); (ii) standard deviation; (iii) mean and (iv) standard error of the mean, sample number $n=80$ and period of analysis (May 2012-October 2013).

\begin{tabular}{ccccc}
\hline Stormwater Inflow Parameters & Range & Std. Deviation & Mean & Std. Error of Mean \\
\hline Water Sample Temp $\left({ }^{\circ} \mathrm{C}\right)$ & $12.0-21.0$ & 1.15 & 15.71 & 0.64 \\
$\mathrm{pH}$ & $6.40-7.70$ & 0.09 & 6.98 & 0.31 \\
Conductivity $(\mu \mathrm{S} / \mathrm{cm})$ & $567.0-1095.0$ & 165.02 & 830.63 & 44.30 \\
Nitrate-Nitrogen $\left(\mathrm{NO}_{3}-\mathrm{N}, \mathrm{mg} / \mathrm{L}\right)$ & $0.17-4.03$ & 0.81 & 2.16 & 0.32 \\
Phosphate ion $\left(\mathrm{PO}_{4}{ }^{3-}, \mathrm{mg} / \mathrm{L}\right)$ & $1.12-8.15$ & 2.18 & 3.31 & 0.52 \\
Chemical Oxygen Demand $(\mathrm{COD}, \mathrm{mg} / \mathrm{L})$ & $101.0-390.0$ & 103.16 & 205.54 & 38.58 \\
Dissolved Oxygen $(\mathrm{DO}, \mathrm{mg} / \mathrm{L})$ & $5.80-8.7$ & 0.88 & 7.52 & 0.49 \\
Total Suspended Solids $(\mathrm{mg} / \mathrm{L})$ & $15.3-86.5$ & 16.33 & 41.73 & 4.03 \\
\hline
\end{tabular}


Table 3 shows the average concentrations of the measured water quality parameters at the outflow. Thus the effectiveness of the geotextile layer within the filters can be directly compared. The MANOVA statistical procedure that was used tested the means for $\mathrm{COD}, \mathrm{NO}_{3}-\mathrm{N}, \mathrm{PO}_{4}{ }^{3-}$, and $\mathrm{TSS}$ outflow concentrations. The MANOVA procedure found that there were no significant differences found between the mean outflow concentrations between Filter Rig No. 2 and Filter Rig No. 3 $(p>0.05)$. However, the MANOVA test did find that both rigs that contained one or more geotextile layers showed statistical differences in all the water parameter outflow concentrations when measured against the results obtained from Filter Rig No. $1(p<0.05)$. This initial finding appears to confirm that inclusion of a cost effective geotextile layer within the standard granular filter system does enhance particulate removal and biochemical treatment performance, but that the addition of further layers do not improve upon the extent of treatment achieved, even though they achieve the same treatment level with a $15 \%$ reduction in overall granular filter layer thickness. Thus this initial work appears to indicate that significant savings could be made by including several geotextile layers at judicious points within the granular filter system. However this does not take into account any impact on the overall hydraulic performance which will be discussed in a later section.

Table 3. Overall measured outflow-Mean (and Standard Deviation) of various effluent characteristics for each pilot granular filter rig, sample number $n=80$ and period of analysis (May 2012-October 2013).

\begin{tabular}{cccc}
\hline \multirow{2}{*}{ Water Quality Parameters } & $\mathbf{1}$ & Granular Filters \\
\cline { 2 - 4 } & $20.94 \pm(2.01)$ & $20.11 \pm(2.02)$ & $\mathbf{2}$ \\
\hline Water Sample Temp $\left({ }^{\circ} \mathrm{C}\right)$ & $6.98 \pm(0.35)$ & $6.94 \pm(0.23)$ & $7.01 \pm 0.16$ \\
$\mathrm{pH}$ & $783.49 \pm(122.34)$ & $744.50 \pm(132.21)$ & $725.18 \pm(137.90)$ \\
Conductivity $(\mu \mathrm{S} / \mathrm{cm})$ & $1.21 \pm(0.24)$ & $1.16 \pm(0.88)$ & $1.07 \pm(1.05)$ \\
Nitrate-Nitrogen $\left(\mathrm{NO}_{3}-\mathrm{N}, \mathrm{mg} / \mathrm{L}\right)$ & $2.18 \pm(1.15)$ & $1.87 \pm(0.34)$ & $1.74 \pm(0.68)$ \\
Phosphate ion $\left(\mathrm{PO}_{4}{ }^{3-}, \mathrm{mg} / \mathrm{L}\right)$ & $76.60 \pm(37.31)$ & $69.81 \pm(26.23)$ & $63.70 \pm(31.44)$ \\
Chemical Oxygen Demand $(\mathrm{COD}, \mathrm{mg} / \mathrm{L})$ & $7.25 \pm(0.92)$ & $7.63 \pm(0.87)$ & $7.42 \pm(0.83)$ \\
Dissolved Oxygen $(\mathrm{DO}, \mathrm{mg} / \mathrm{L})$ & $4.86 \pm(3.27)$ & $3.37 \pm(4.15)$ & $2.15 \pm(2.31)$ \\
Total Suspended Solids $(\mathrm{TSS}, \mathrm{mg} / \mathrm{L})$ & &
\end{tabular}

\subsection{Turbidity and Suspended Solids}

The relationship between the effluent turbidity and suspended solids varied depending on the concentrations present within the gully pots themselves and the frequency of rainfall events. Figure 4 shows the relationship between the effluent turbidity and suspended solids concentrations for Filter Rig No. 1 (no geotextile layer). A strong linear correlation existed for all three rigs with respect to outflow turbidity measurements and the suspended solids concentrations $\left(R^{2}=0.88\right)$.

\subsection{Hydraulic Characteristics and Water Quality}

The method for testing the hydraulic flow rate through the three experimental rigs occurred periodically. An average flow rate of $600 \mathrm{~L}$ per hour with de-ionised water was poured onto each filter rig. The mean effluent flow rates were recorded, and are represented graphically in Figure 5. It can be clearly seen that the flow rates are reduced significantly by the presence of the geotextile layer. The 
highest hydraulic conductivity occurs in Filter Rig No. 1 consisting simply of gravel, pea gravel and sand. Consequently, these results indicate that judicous use of geotextile layering whilst enhancing treatment performance, will, nevertheless, adversely impact on volume throughput, and the more the number of geotextile layers, the slower the percolation rate, since each layer has its own biofilm growth which increases geomembrane selectivity, thereby reducing localised flow rates even more. On a more positive note, over the entire five month experimental period, the overall hydraulic flow rates for each rig were not greatly impaired by clogging since at no time was back washing ever needed. Nevertheless, for a longer operational period or a heavier system loading, it is anticipated that backwashing would eventually be required on a periodic basis. Therefore in summary, it appears that even though two or more layers of geotextile may allow reductions in overall depths of granular filter media used, this is at the expense of volume throughput which can be significantly decreased. This could be a real problem if the surrounding soil type has a low permeability and the overall granular filter system has a subsequent reduced storage volume, i.e., potential for micro flooding events to occur.

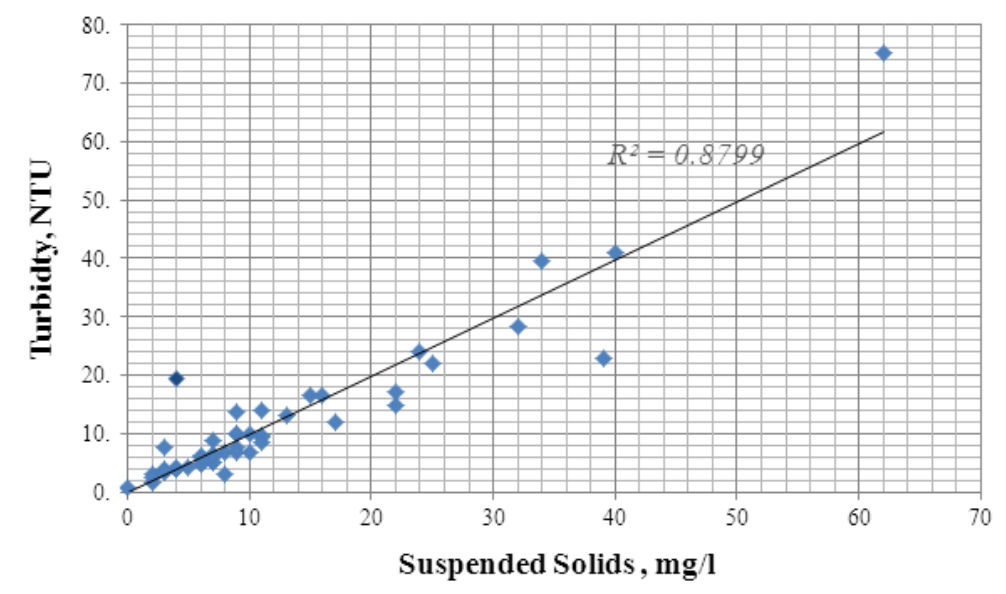

Figure 4. Relationship between mean inflow concentrations for Turbidity (NTU) and Suspended Solids (mg/L) for Filter Rig No. 1.

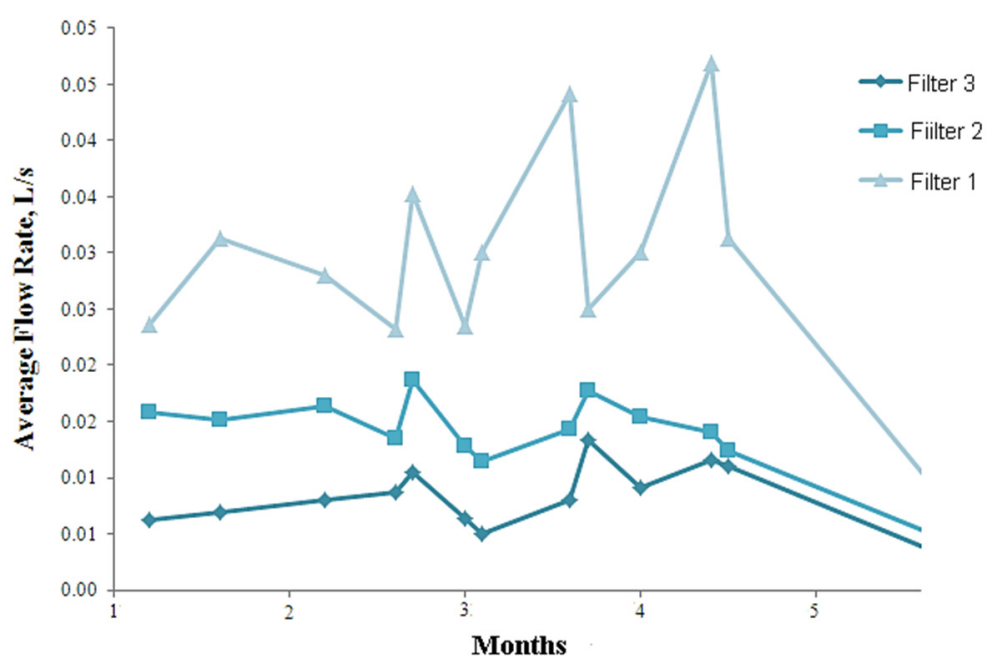

Figure 5. Average effluent flow rates during the period of May-September 2013 (After 1 year of operation). 
The amount of COD removed by each rig was an important measure. High levels of COD can have eco-toxic effects on aquatic organisms and consists of potentially harmful substances such as heavy metals, polycyclic aromatic hydrocarbons (PAHs), and organic matter. As a result of the high COD loading, the filters removed on average $30 \%$ to $50 \%$ of it. In terms of the organic matter (as COD) there were mean differences found between Filter Rig No. 1, Filter Rig No. 2 (upper geotextile membrane) and Filter Rig No. 3 (upper and lower geotextile membrane) as illustrated in Figure 6. Overall Filter Rig No. 3 generally achieved the best removal as expected due to the biofilms formed on each of the upper and lower geotextiles layers which enhances geomembrane selectivity and subsequent treatment efficacy.

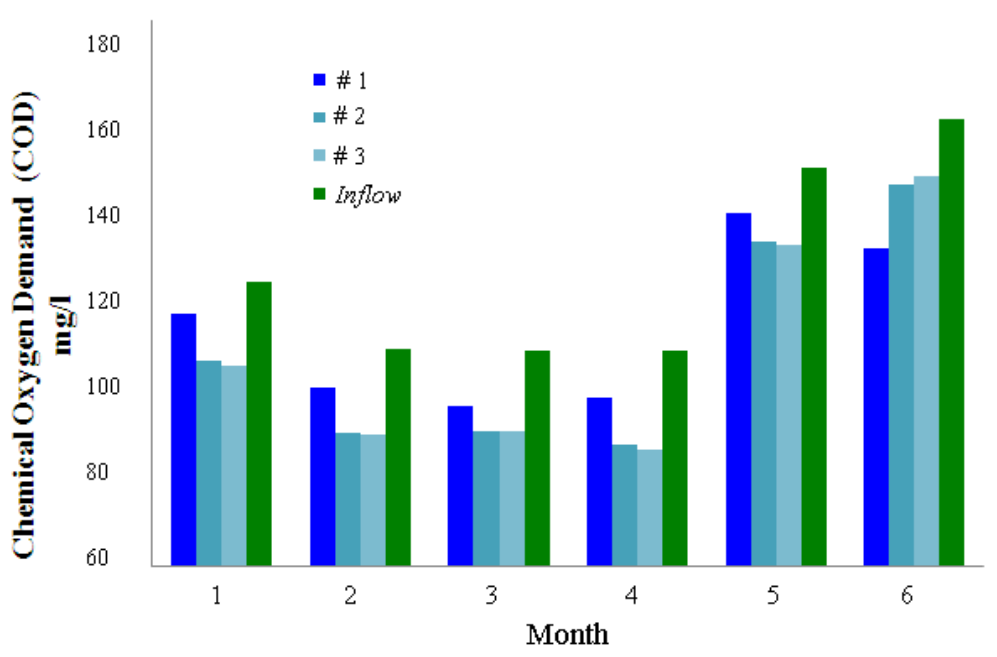

Figure 6. Chemical oxygen demand (COD), $\mathrm{mg} / \mathrm{L}$ influent and effluent concentrations from May to October 2013.

Nitrogen is an essential nutrient that is required for cell growth. Organic nitrogen and ammonia $\left(\mathrm{NH}_{3}\right)$ present in the inflow stormwater requires oxygen for oxidation to nitrite $\left(\mathrm{NO}_{2}\right)$ and nitrate $\left(\mathrm{NO}_{3}\right) . \mathrm{NH}_{3}$ in the inflow can be converted to $\mathrm{NO}_{2}$ by nitrosomonas bacteria and further converted to $\mathrm{NO}_{3}$ via nitrobacter bacteria if the treatment system permits sufficient retention time. However, the process of endogenous respiration occurring to the microbial species that make up the biofilm can release further $\mathrm{NH}_{3}$ which can lead to negative $\mathrm{NO}_{3}$ removal rates as shown in Figure 7. In this initial study, the extent of nitrogen in its nitrate form that was further converted to nitrogen gas $\left(\mathrm{N}_{2}\right)$ was not measured. This can occur if conditions are optimal for denitrifying bacteria to grow (i.e., anaerobic and sufficient carbon sources exist). Accumulation of nitrates in still or slow moving bodies of water can lead to eutrophication which is the process whereby increased concentrations of nutrients can cause rapid growth of algal biomass. Hence further treatment for the removal of nitrogen based compounds may be required depending on the applicability of any water reuse scheme.

\subsection{Biofilm Formation}

The formation of biofilm within the filters begins with the attachment of free floating microorganism to the geotextile surface. The single geotextile layer present within Filter Rig No. 2 positioned between gravel (coarse gravel) and pea gravel layers revealed a thick biofilm zone from the 
microscopic photographs (Figure 8). The biofilm layers resemble that of a thick "slime" surrounding the geotextile, and would be composed of soluble microbial products (SMP) released by the attached microbial species. This SMP, sometimes also referred to as extra-cellular polymeric substances (EPS) would itself be composed of proteins and polysaccharides that sloughed off from the active microbial biomass forming the biofilm. This SMP/EPS would increase geomembrane selectivity since they would both reduce the geotextile pore sizes and act as active attachment agents for particulates much smaller than the average pore spacing. In Figure 8, for the higher magnification photograph, it can be clearly seen that the layer appears to contain small sediments and particles that have been trapped from the influent stormwater by the SMP/EPS in the biofilm.

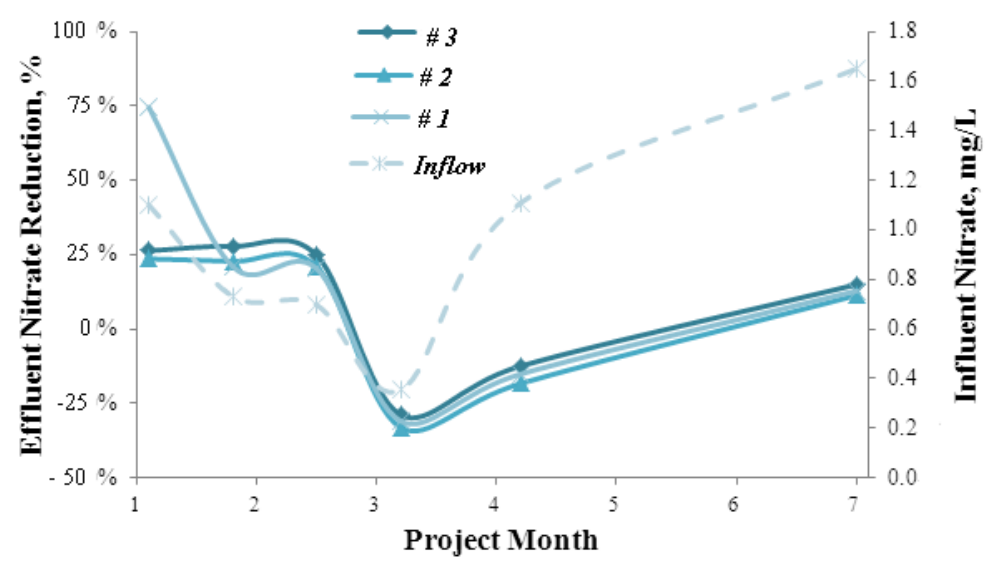

Figure 7. Nitrate-nitrogen $\left(\mathrm{NO}_{3}-\mathrm{N}\right)$ removal percentages and inflow $\mathrm{NO}_{3}-\mathrm{N}$ concentrations $(\mathrm{mg} / \mathrm{L})$ from May to October 2013.

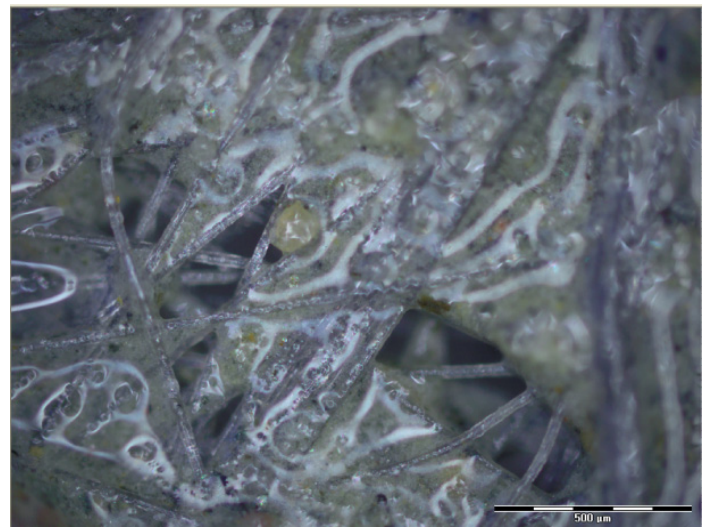

(a)

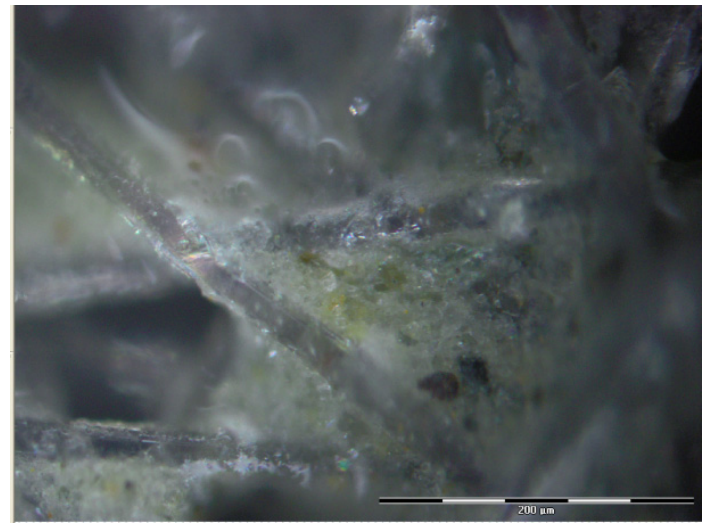

(b)

Figure 8. Filter Rig No. 2 geotextile layer at $5 \times$ magnification (a); and $20 \times$ magnification (b).

The photographs illustrated in Figure 8 also reveal the composition of the biofilm at different magnification levels. The biofilm fills some gaps, but there still exist open pore spaces enabling the free movement of the water under gravity. The twenty times $(20 \times)$ magnification image clearly reveals organic matter trapped in the biofilm. Biological growth was also observed in the pea gravel layer just beneath the geotextile for Filter Rig No. 2.

Figure 9 shows the upper geotextile layer within Filter Rig No. 3 at a magnification of $20 \times$. The images focus on the fibres' surfaces and in between the fibres. As expected, the SMP/EPS that makes 
up the biofilm entraps much smaller particles in the percolating stormwater whilst there are still sufficient pore spaces to allow the natural movement of the liquid. On the other hand, for the lower geotextile layer in Filter Rig No. 3, it displays the most observable pore spaces at five times $(5 \times)$ magnification (Figure 10) due to reduced biofilm growth. This reduction is as anticipated since a large portion of the organic substrate in the stormwater would already have been removed by the initial upper geotextile layer meaning there would be less available to feed any attached microbial biomass growing on the lower layer. Thus the overall extent of biofilm formation is much less than on the upper geotextile since it has less loading on it biochemically speaking. Hence, the biofilm is localised to areas where the pore space between the fibers is fairly small, for example the gaps between intersections of the fibres.

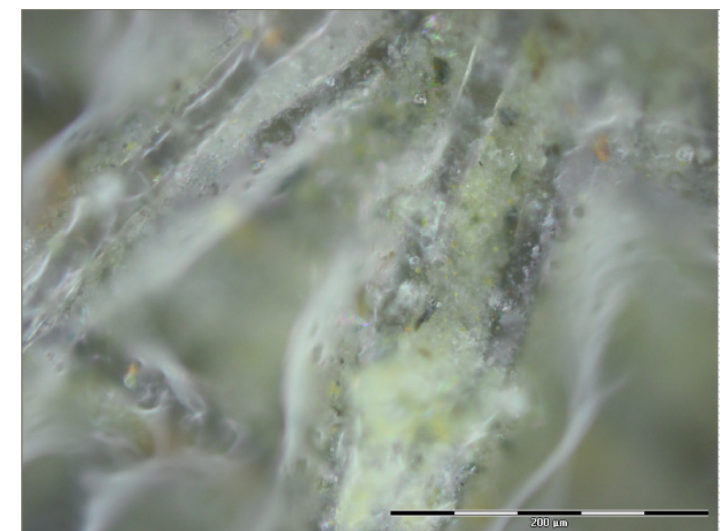

(a)

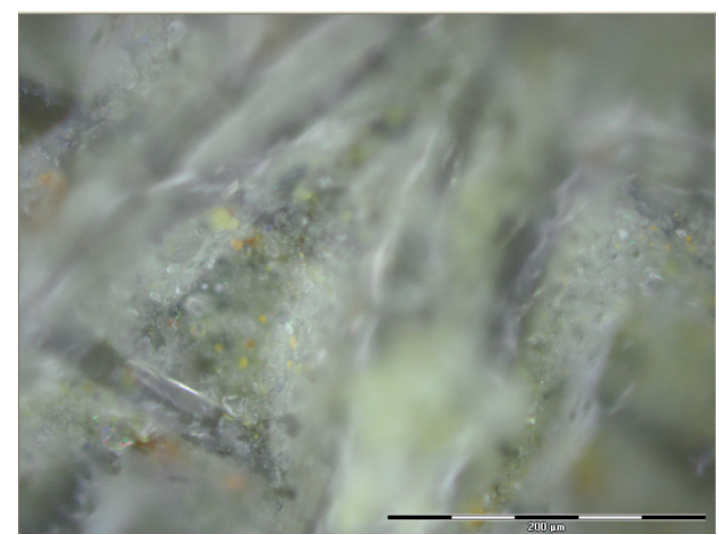

(b)

Figure 9. Filter Rig No. 3 upper geotextile layer at 20× magnification; focusing on fibres (a); and focusing between fibres (b).

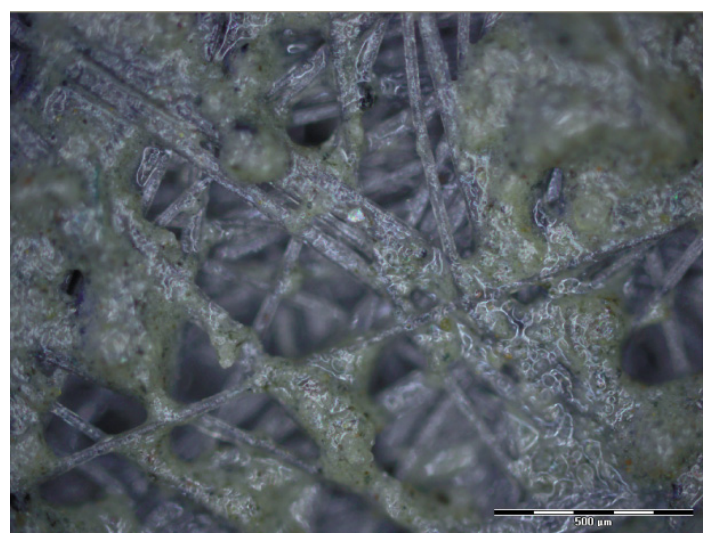

(a)

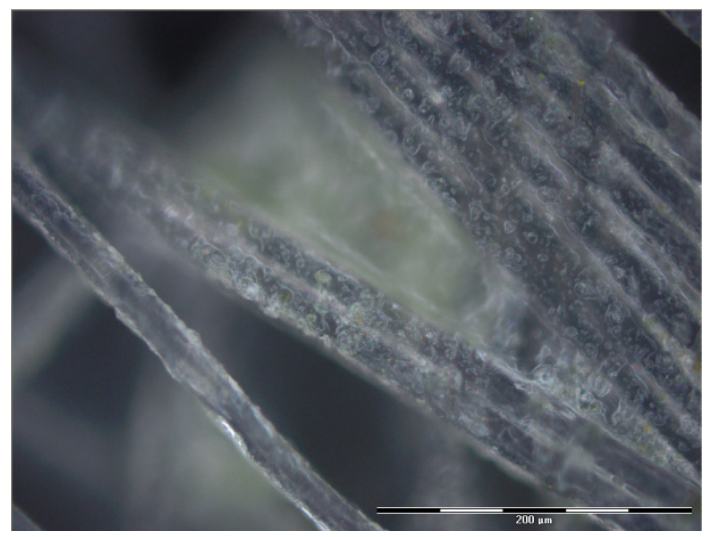

(b)

Figure 10. Filter Rig No. 3 lower geotextile at $5 \times$ magnification (a); and $20 \times$ magnification (b).

Whilst there is not a large accumulation of biofilm between the fibres of the lower geotextile in Filter Rig No. 3, there is continuous accumulation on the surface of the fibres. Additionally, the biofilm formed appears less dense in nature as well. Thus from the point of view of saving the volume of material used that makes up the granular filter media, this geotextile layer does perform adequately by increasing selectivity with sufficient biofilm growth. 


\section{Conclusions}

This project investigated the judicious use of nonwoven geotextiles as one or more layers placed in a stormwater treatment system. It showed the development of biological treatment; the essential characteristics of the biofilm surrounding the geotextile layer/s; the impact of the layer/s on the hydraulic loading capacity as well as potential reductions in overall volumes of granular material to be used in the system. The key findings of this study were as follows:

- The hydraulic conductivity was highest for the rig with no layers of geotextile, and conversely the experimental rig with two layers of geotextile membranes outperformed the other two rigs with regards to nutrient and substrate removal.

- The generation of significant biofilm around the geotextile zone resulted in higher organic pollutant retention. The growth and thickness of the biofilm varied depending on the number of geotextile membrane layers used. Subsequent SMP/EPS formation within the biofilm allowed improved geomembrane selectivity by removing smaller particulates than would otherwise be possible when compared to the size of the geotextile pores.

- Nitrate removal efficiencies were generally low and occasionally resulted in the reconversion of ammonia and nitrites to nitrates as a result of the reduced nitrogen leaching pathways; the fluctuating loads from the sources of stormwater; and, low initial concentrations of nitrates.

- As a result of the sporadic influx of stormwater pollutants throughout each filtration system, high hydraulic loadings, and the lack of maintenance via back-washing, the geotextile layer/s can eventually become scored thus potentially allowing removal of the active biofilm zone. This results in reduced system effectiveness for water pollutant retention. This appears to have occurred at the tail-end of the experimental period.

- Follow on work will look at the reduction in geotextile membrane hydraulic flux based on the production of SMP/EPS due to biofilm growth. Additionally, biofilm formation models will be developed that take into account the classical fouling mechanisms involved in biofilm production [17]. These models can further aid in understanding the complex processes involved within and around the geotextile surface.

In summary, depending on the perceived public health risk and volumes of stormwater requiring treatment, this initial work appears to indicate the best system configuration would include both an upper and a lower geotextile membrane for optimal water infiltration and higher efficiencies of treatment, while potential simultaneous reductions in volumes of granular material could also be achieved. However, this would be offset by significant reductions in hydraulic transmission rates and subsequent low volume throughputs that would be need to be catered for in any design. More experimental work is required to confirm these initial findings.

\section{Acknowledgments}

This project was financially supported by Brunel University's Department of Civil Engineering and its Water Sustainability Research Centre. The authors would like to thank the visiting researchers from the National School for Water and Environmental Engineering in Strasbourg, France for their support in carrying out the experimental project work at Brunel University's dedicated water research facilities. 


\section{Author Contributions}

The experimental work, data processing, and modelling work in this study were carried out in Brunel University's Water Process Lab under the direction of project supervisor Parneet Paul with some follow-on assistance from Kiran Tota-Maharaj. The first draft of the original manuscript was prepared by Parneet Paul and later versions were revised and edited by Kiran Tota-Maharaj.

\section{Conflicts of Interest}

The authors declare no conflict of interest.

\section{References}

1. Guyer, P. Introduction to Geotextiles in Pavement and Drainage Applications. Available online: http://www.cedengineering.com/upload/An\%20Intro\%20to\%20Geotextiles\%20in\%20Pave\%20Dr ain\%20Apps.pdf (accessed on 1 August 2013).

2. Yaman, C.; Martin, J.P.; Korkut, E. Use of Layered Geotextiles to Provide a Substrate for Biomass Development in Treatment of Septic Tank Effluent Prior to Ground Infiltration. J. Environ. Eng. 2005, 131, 1667-1675.

3. Korkut, E.; Martin, J.; Yaman, C. Wastewater Treatment with Biomass Attached to Porous Geotextile Baffles. ASCE J. Environ. Eng. 2006, 132, 284-288.

4. Tota-Maharaj, K.; Grabowiecki, P.; Babatunde, A.; Coupe, S.J. The performance and effectiveness of geotextiles within permeable pavements for treating concentrated stormwater. Int. Water Technol. J. 2012, 2, 207-216.

5. Koerner, R.M. Designing with Geosynthetics, 4th ed.; Upper Saddle River: Prentice-Hall, NJ, USA, 1998.

6. Giroud, J.P. Development of criteria for geotextile and granular filters. In Proceedings of the 9th International Conference on Geosynthetics, Guaruja, Brazil, 23-27 May 2010; pp. 45-64.

7. Palmeira, E.M.; Gardoni, M.G. Drainage and filtration properties of non-woven geotextiles under confinement using different experimental techniques. Geotext. Geomembr. 2002, 20, 97-115.

8. Koerner, G.; Koerner, R. Leachate flow rate behavior through geotextile and soil filters and possible remediation methods. Geotext. Geomembr. 1992, 11, 401-430.

9. House, C.H.; Bergmann, B.A.; Stomp, A.M.; Frederick, D.J. Combining constructed wetlands and aquatic and soil filters for reclamation and reuse of water. Ecol. Eng. 1999, 12, 27-38.

10. Tota-Maharaj, K.; Paul, P. Investigating the influence of geotextile layers as biofilm granular filters to treat stormwater. Urban Water J. 2015, doi:10.1080/1573062X.2014.916726.

11. Vanlandingham, D.S.; Gross, M.A. Contaminant distribution in intermittent sand filters. Trans. ASAE Am. Soc. Agric. Eng. 1998, 3, 380-387.

12. Gourc, J.P.; Faure, Y.H. Filter Criteria for Geotextiles. In Proceedings of the 4th International Conference on Geotextiles, Geomembranes and Related Products, The Hague, The Netherlands, 28 May-1 June 1990; Volume 3, pp. 949-971.

13. Butler, D.; Davies, J.W. Urban Drainage, 2nd ed.; Spon Press: London, UK, 2004. 
14. American Public Health Association (APHA). Standard Methods for the Examination of Water and Wastewater, 12th ed.; APHA/American Water Works Association/Water Environment Federation: Washington, DC, USA, 1998.

15. Hach Company. Hach ${ }^{\circledR}$ Digital Reactor Block 200 (DRB200) Instrument Manual; Hach Company: Loveland, CO, USA, 2003.

16. Hach Company. Hach ${ }^{\circledR}$ DR/820, Colorimeter Procedures Manual; Hach Company: Loveland, CO, USA, 2004.

17. Hermia, J. Constant Pressure Blocking Filtration Laws Application to Power-Law Non-Newtonian Fluids. Trans. Inst. Chem. Eng. 1982, 60, 83-187.

(C) 2015 by the authors; licensee MDPI, Basel, Switzerland. This article is an open access article distributed under the terms and conditions of the Creative Commons Attribution license (http://creativecommons.org/licenses/by/4.0/). 